\title{
JUURNAL.RU
}

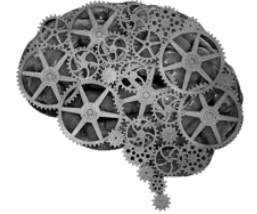

COMPANY GROUP "INTELLEKT"

Дорогова К.С., Дорогов А.Ф., Кривенцов Н.М., Храмова А.А., Пичхидзе С.Я. СГТУ имени Ю.А. Гагарина

Саратов, Россия

doi: 10.18411/lj2016-6-2-05

\section{Разработка новой конструкции дентального имлантата}

Имплантация зубов позволяет успешно решать проблемы зубного протезирования в сложных случаях.

Целью работы являлось усовершенствование конструкции имплантата, улучшение остеоинтеграции. Недостатки прототипа: отторжение костной ткани, плохое сцепление с десной [1]. Предложенный имплантат включает в себя, рис. 2:

1. Коническую форму - обеспечивает вертикальную и горизонтальную конденсацию имплантного ложа при установке, для достижения первичной стабильности имплантата,

2. Двойную резьбу - создает умеренную компрессию кости, улучшает контакт кость-имплантат, ускоряя процесс остеоинтеграции и обеспечивая долговременный клинический результат. Диаметр резьбы увеличивается от апекса к шейке имплантата от 3,70 до 4,20 мм с шагом - 2,40 мм,

3. Микрокольца на шейке имплантата увеличивают площадь контакта имплантата с костью в пришеечной области имплантного ложа, что в свою очередь исключает риск резорбции костной ткани в крестальном отделе альвеолярного отростка, шаг 1,5 мм, 


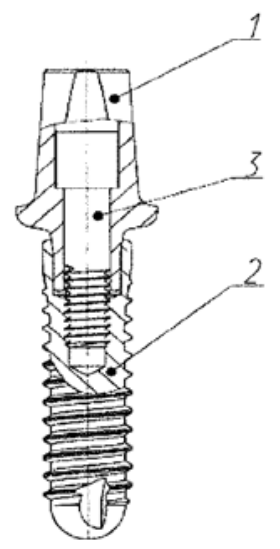

Рис.1. Винтовой стоматологический эндопротез - прототип (1-абатмент, 2эндопротез, 3- винт-заглушка)

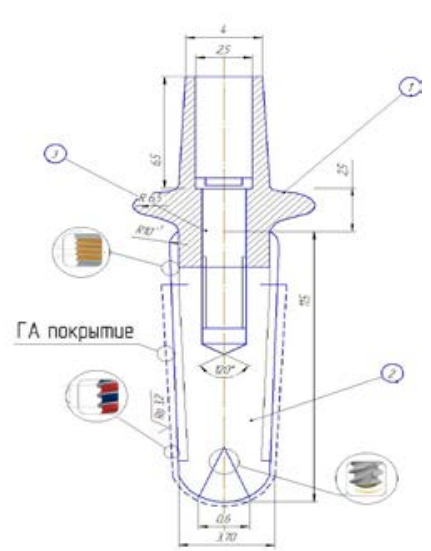

Рис.2. Имплантат цилиндрический винтовой (1-абатмент, 2- эндопротез, 3винт-заглушка)

4. Имплантаты обработаны по системе SLA (Sand-blasted, Large grit, Acid-etched, крупнозернистая пескоструйная обработка и травление кислотой), в результате образуются шероховатость и микродизайн поверхности,

5. Имплантат имеет соединение типа - внутренний шестигранник, что обусловливает отличное прилегание и удобное позиционирование супраструктуры, а также обеспечивает высокую и долговременную эстетику ортопедической конструкции. Диаметр шестигранника составляет - 2,45 мм,

6. Спиральный канал имплантата, расположенный в его апикальной части, обеспечивает его самонарезающие свойства и делает процедуру имплантации простой, контролируемой и безопасной,

7. Имплантат имеет режущий апекс, что позволяет проводить окончательную корректировку направления имплантата при установке [2],

8. Антимикробное биосовместимое покрытие состоит из цинкгидроксиапатита [3, 4]. 
Выводы: новая конструкция обеспечивает максимальную остеоинтеграцию, приводя в устойчивость эндопротез и его способность выполнять функцию опоры зубного протеза и нести значительную механическую нагрузку при жевании.

\section{Литература:}

1. Патент РФ 95501 от 25.01.2010 / Винтовой стоматологический эндопротез // Солодкий В. Г., Иванов С.Ю., Ларионов Е.В., Мураев А.А., Солодкая И. B.

2. http://liment.ru/mis/surgery/implants/seven.

3. Фадеева И.В. Цинк и серебросодержащие гидроксиапатиты: синтез и свойства / И.В. Фадеева, Н.В. Бакунова, В.С. Комлев, Л. Медвецкий, А.С. Фомин, А.Н. Гурин, С.М. Баринов // ДАН, 2012, т.442, № 6.- С. 780-783.

4. Минаева О.Н., Перинская И.В., Пичхидзе С.Я. Усовершенствование конструкции дентального имплантата и усиление его антимикробных свойств. Тенденции науки и образования в современном мире 